\title{
THE
}

\section{Gerontological Social Work Roles in Disaster Preparedness and Response}

Nancy Kusmaul

Allison Gibson

Skye N. Leedahl

University of Rhode Island, skyeleedahl@uri.edu

Follow this and additional works at: https://digitalcommons.uri.edu/hdf_facpubs

The University of Rhode Island Faculty have made this article openly available.

Please let us know how Open Access to this research benefits you.

This is a pre-publication author manuscript of the final, published article.

Terms of Use

This article is made available under the terms and conditions applicable towards Open Access Policy Articles, as set forth in our Terms of Use.

\section{Citation/Publisher Attribution}

Nancy Kusmaul, Allison Gibson \& Skye N. Leedahl (2018) Gerontological Social Work Roles in Disaster Preparedness and Response, Journal of Gerontological Social Work, 61:7, 692-696, DOI: 10.1080/ 01634372.2018 .1510455

Available at: https://doi.org/10.1080/01634372.2018.1510455

This Letter to the Editor is brought to you for free and open access by the Human Development and Family Science at DigitalCommons@URI. It has been accepted for inclusion in Human Development and Family Science Faculty Publications by an authorized administrator of DigitalCommons@URI. For more information, please contact digitalcommons-group@uri.edu. 
Gerontological Social Work Roles in Disaster Preparedness and Response

\author{
Nancy Kusmaul \\ University of Maryland Baltimore County \\ Allison Gibson \\ University of Kentucky \\ Skye N. Leedahl \\ University of Rhode Island
}

Correspondence concerning this letter should be addressed to:

Nancy Kusmaul

Department of Social Work

University of Maryland Baltimore County

1000 Hilltop Circle

Baltimore, MD 21250

Email: nkusmaul@umbc.edu 


\section{Dear Editor-in-Chief,}

While natural and manmade disasters have always existed, the increase in the frequency of disaster events, growing evidence that older adults are disproportionately negatively impacted by disasters, and a larger number of older adults comprising the world's population have compelled us to write this letter to the editor to consider social work's role in enhancing older adults' well-being and safety in disaster events. While social workers in the U.S. are often not explicitly trained for disasters, their experience in assessing community strengths and needs, crisis response, and their ability to organize disparate groups has prepared them to contribute to municipal disaster planning. Social workers must consider the unique needs of older adults across the three crisis event phases: pre-disaster preparedness, post-disaster response, and long term disaster recovery.

\section{Role of Social Work in Mitigation and Disaster Preparedness}

To prepare older adults for disasters, social workers should:

- Assess for unique needs, risk factors, and strengths. In disasters, older adults can be vulnerable due to age-related changes (Torgusen \& Kosberg, 2008), such as chronic conditions, limitations in activities of daily living (ADLs) and instrumental activities of daily living (IADLs), physical and cognitive disabilities, and/or sensory impairments (Aldrich \& Benson, 2008; Dyer, Regev, Burnett, Festa, \& Cloyd, 2008; Weisler, Barbee $\&$ Townsend, 2006). Knowing the risk factors of serious threats to health and safety for older adults during disasters can help social workers better prepare clients (Einsenman, Cordasco, Asch, Golden \& Glki, 2007; Eisenman et al., 2009).

- Provide or facilitate education on preparedness. Helping older adults prepare for disasters using comprehensive disaster plans can mitigate much of the physical, social, 
and emotional damage that can occur as a result of disasters (Al-Rousan, Rubinstein, \& Wallace, 2014). Many older adults do not have an emergency plan, basic supplies or know where to find resources for disaster preparedness; about $14 \%$ would need electricity to keep medical devices working (Al-Rousan et al., 2014). Programs such as PrepWise, can train older adults for disaster preparedness (Ashida, Robinson, Gay, Slagel, \& Ramirez, 2017), and social workers can share with older adults the many materials created to help them plan for disasters (e.g., American Red Cross, 2009; Fordyce, Kenny, \& Oettinger, 2006; U.S. Department of Homeland Security, n.d.).

- Establish support for the disaster plan. Older adults can be empowered to take responsibility for disaster planning (Fernandez, Byard, Lin, Benson, \& Barbera, 2002). Social workers can help older adults and their families create customized emergency plans to reflect the individual's needs, existing resources, and networks, and informal supports such as families and neighbors. Mobilizing neighbors may also be a method for social workers to ensure older adults have support in the case of a disaster.

- Help with enrollment for assistance registries. In some communities, older adults and persons with disabilities can sign up for a registry so that emergency operations managers know where they are and what they may need in an emergency. Social workers working with community-dwelling older adults can encourage at-risk, socially isolated individuals to sign up for these types of registries and understand the confidentiality and privacy of such registries (Elmore \& Brown, 2007).

\section{Role of Social Work in Responding to the Disaster}

Following a disaster, social workers should: 
- Provide education about shelter and evacuation. When deciding to evacuate or shelter in place, an individual must know about available choices and make a plan. This information must be made readily available by the community to help inform older adults who may be reliant on social supports or external resources (Gibson, Walsh \& Brown, in press). Social workers must advocate for community education regarding resources available in shelter and disaster recovery settings.

- Address decision-making barriers. Social workers should remind individuals and families that they need to maintain as much normalcy and routine as possible for recovery (Naturale, 2018). Yet sometimes evacuation is necessary. Seniors are more likely to respond to mandatory evacuation orders than voluntary evacuation requests (GrayGraves, Turner, \& Swan, 2011). One barrier to evacuation for older adults is not wanting to leave a pet behind (Torgusen \& Kosberg, 2008). The Pet Evacuation Transportation Standards (PETS) Act of 2006 authorized recovery options for individuals to evacuate with their pets (The White House, 2005). Social workers must advocate further for the needs of older adults post-disaster.

- Assess impact of displacement and relocation. Displacement and relocation are common outcomes of a major disaster. Relocation can trigger long-term stressors, and may increase the risk of fatality (Chao, 2017; Norris, Friedman, \& Watson, 2002). While some older adults can go home after post-disaster rebuilding, many permanently relocate (Binder, Baker \& Barile, 2015). Social workers need to be aware of these impacts when a senior arrives in their community due to a disaster event.

- Consider the most vulnerable. Older adults in nursing homes are especially vulnerable during disasters due to physical and cognitive frailty. Nursing homes face the same 
critical decision as individuals of whether to evacuate or shelter in place (Dosa et al., 2008) and have to assess the same concerns (i.e., safety, power), complicated by complex resident needs including end-of-life care (Frahm \& Brown, 2011). Residents rely on staff to make decisions for them in crises, yet staff are often not trained in disaster decision making. Claver et al. (2013) examined experiences of Veterans Affairs' nursing homes during disaster evacuations and found multiple issues that could have been mitigated by social work involvement in well-crafted disaster drills.

\section{Role of Social Work in Disaster Recovery}

To help with disaster recovery, social workers need to:

- Assess and treat traumatic stress. Social workers must be familiar with disaster mental health trends and cultural considerations that may accompany traumatic response in older adults, such as how exposure to a disaster increases risk for posttraumatic stress disorder (PTSD) (e.g., Galea, Tracy, Norris, \& Coffey, 2008; Pietrzak, Goldstein, Southwick, \& Grant, 2012). Social work clinicians need to be prepared to refer or provide older populations with evidence-based PTSD treatment. While there are numerous evidenceinformed treatments available for conditions that can result from mass trauma, few studies have tested these interventions on older adults (Gibson, Walsh \& Brown, 2017).

- Assess financial stress. Financial stress can also affect the emotional well-being of older adults and their families during long term disaster recovery. Older adults are more likely to suffer significant financial losses after disaster than younger groups (Al-Rousan et al., 2014) with shorter time horizons in which to recoup losses (Walsh, Gibson \& Brown, 2016). Social workers are well-suited to assist older adults in identifying resources to 
address financial gaps, and to advocate for federal and state programs that can address their specific needs.

- Address community loss. Community loss includes physical damage, financial loss, and shared grief. Immediately post-disaster, communities may become united. After the September 11, 2001 terrorist attacks, the country rallied around the phrase, "United We Stand." Later, when communities begin having conversations about using funds for recovery, building, and planning memorials, these discussions can become quite ardent (Shughart, 2006). Social workers may need to provide conflict resolution for these community conversations. For older adults, social workers should work on interprofessional teams to determine if the disaster has resulted in service limitations or other negative impacts for older persons in their community (e.g. Gibson \& Hayunga, 2006).

- Build community resilience. Developing community resilience greatly supports the well-being of older adults. While communities tend to consider community resilience following a disaster, social workers should facilitate conversations about community resilience in the disaster planning stages. One way that communities may incorporate resilience planning is through age-friendly community planning, which provides guidelines for considering the needs of older community residents (Chandra et al., 2018). In conclusion, many social workers feel unprepared to respond to disasters. Many current professionals have only learned about the role of social work in disasters when their community was affected by a disaster event. Continuing education trainings that review disaster planning and response will enhance the social work profession's capacity to assist in preparing for and responding to disaster. Social work professionals must share their experiences in disaster. The 
social work profession needs first-hand accounts about what happened, what went well, and what did not go well. Learning from mistakes will provide guidance about best practices for assisting older adults in disasters. It cannot be overstated the importance of having well-trained and aging competent professionals to support older adults affected by disasters. Social workers have the training, knowledge, and experience to advocate for the unique needs of older adults in disasters and need to take on this important mission.

Sincerely,

Nancy Kusmaul

University of Maryland Baltimore County

Allison Gibson

University of Kentucky

Skye N. Leedahl

University of Rhode Island 


\section{References}

Al-Rousan, T. M., Rubenstein, L. M., \& Wallace, R. B. (2014). Preparedness for natural disasters among older US adults: A nationwide survey. American Journal of Public Health, 104(3), 506-511. doi:10.2105/AJPH.2013.301559

Aldrich, N. \& Benson, W.F. (2008). Disaster preparedness and the chronic disease needs of vulnerable older adults. Center for Disease Control and Prevention. Retrieved from http://www.cdc.gov/pcd/issues/2008/jan/pdf/07_0135.pdf.

American Red Cross. (2009) Disaster preparedness for seniors by seniors. Retrieved from http://www.redcross.org/images/MEDIA_CustomProductCatalog/m4640086_Disaster_Pr eparedness_for_Srs-English.revised_7-09.pdf

Ashida S., Robinson E.L., Gay J., Slagel, L.E., \& Ramirez M.R. (2017). Personal disaster and emergency support networks of older adults in a rural community: Changes after participation in a preparedness program. Disaster Medicine and Public Health Preparedness, 11(1), 110-119. doi:10.1017/dmp.2016.197

Binder, S.B., Baker, C.K., \& Barile, J.P. (2015). Rebuild or relocate? Resilience and postdisaster decision-making after Hurricane Sandy. American Journal of Community Psychology, 56(1-2):180-196. doi: 10.1007/s10464-015-9727-x.

Chandra, A., Acosta, J., Stern, S., Uscher-Pines, L., Williams, M.V., Yeung, D., ... Meredith, L.S. (2018). Building community resilience to disasters. RAND Health. Retrieved from https://www.rand.org/content/dam/rand/pubs/technical_reports/2011/RAND_TR915.pdf

Chao, S. (2017). Social support, coping strategies and their correlations with older adults' relocation adjustments after natural disaster. Geriatrics \& Gerontology International, 17, 1006-1014. doi: $\underline{10.1111 / g g i .12807}$ 
Claver, M., Dobalia, A., Fickel, J.J., Ricci, K.A., \& Mallers, M.H. (2013). Comprehensive care for vulnerable elderly veterans during disaster. Archives of Gerontology and Geriatrics, 56, 205-213. doi: 10.1016/j.archger.2012.07.010

Dosa, D. M., Hyer, K., Brown, L. M., Artenstein, A. W., Polivka-West, L., \& Mor, V. (2008). The controversy inherent in managing frail nursing home residents during complex hurricane emergencies. Journal of the American Medical Directors Association, 9(8), 599-604. doi: 10.1016/j.jamda.2008.05.007

Dyer, C.B., Regev, M., Burnett, J., Festa, N., \& Cloyd, B. (2008). SWiFT: A rapid triage tool for vulnerable older adults in disaster situations. Disaster Med Public Health Prep, 2(S1), S45-50. doi:10.1097/DMP.0b013e3181647b81

Eisenman, D.P., Cordasco, K.M., Asch, A., Golden, J.F., \& Glik, D. (2007). Disaster planning and risk communication with vulnerable communities: Lessons from Hurricane Katrina. American Journal of Public Health, 97(S1), S109-S115. doi:10.2105/AJPH.2005.084335

Eisenman D.P., Glik D., Gonzalez, L., Maranon, R., Zhou, Q., Tseng, C.H., \& Asch, S.M. (2009). Improving Latino disaster preparedness using social networks. American Journal of Preventative Medicine, 37(6), 512-7. doi: 10.1016/j.amepre.2009.07.022

Elmore, D., \& Brown, L. (2007). Emergency preparedness and response: Health and social Policy implications for older adults. Generations, 31(4), 66-74.

Fernandez, L. S., Byard, D., Lin, C. C., Benson, S., \& Barbera, J. A. (2002). Frail elderly as disaster victims: Emergency management strategies. Prehospital Disaster Medicine, 17(2), 67-74. doi: $\underline{10.1017 / \mathrm{S} 1049023 \mathrm{X} 00000200}$

Fordyce, E.N., Kenny, D.E., \& Oettinger, E. (2006). U.S. Department of Health \& Human 
Services, Administration on Aging. Just in case: Emergency readiness for older adults and caregivers. Retrieved from https://www.acl.gov/sites/default/files/programs/2016-10/Just_in_Case030706_links.pdf Galea, S., Tracy, M., Norris, F. \& Coffey, S.F. (2008). Financial and social circumstances and The incidence and course of PTSD in Mississippi during the first two years after Hurricane Katrina. Journal of Traumatic Stress, 21, 357-368. doi: 10.1002/jts.20355

Gibson, A., Walsh, J. L., Brown, L. M. (2018). A perfect storm: Alzheimer's caregiving during natural disasters. Journal of Gerontological Social Work. Manuscript is published online: https://doi.org/10.1080/01634372.2018.1474158 [Epub ahead of print]

Gibson, A., Walsh, J., \& Brown, L.M. (2017). Disaster mental health services review of care for older persons following disasters. Disaster Medicine and Public Health Preparedness. Manuscript is published online. doi: 10.1017/dmp.2017.60. [Epub ahead of print]

Gibson, M.J., \& Hayunga, M. (2006). We can do better: Lessons learned for protecting older persons in disaster. Washington, DC: AARP. Retrieved from https://assets.aarp.org/rgcenter/il/better.pdf

Gray-Graves, A., Turner, K.W., \& Swan, J.H. (2011). The level of willingness to evacuate among older adults. Gerontology \& Geriatric Education, 32(2), 107-121. doi:10.1080/02701960.2011.572034.

Naturale, A. (2018, March). New evidence informed intervention approaches for social workers responding to natural disasters and other mass casualty events. Presented at the Social Work Hospice \& Palliative Care Network annual meeting. Boston, MA. Norris, F. H., Friedman, M. J., \& Watson, P. J. (2002). 60,000 disaster victims speak: Part II. 
Summary and implications of the disaster mental health research. Psychiatry, 65(3), 240260. doi: $10.1521 /$ psyc. 65.3 .240 .20169

Pietrzak, R.H., Goldstein, R.B., Southwick, S.M., \& Grant, B.F. (2012). Psychiatric comorbidity of full and partial posttraumatic stress disorder among older adults in the United States: Results from wave 2 of the National Epidemiologic Survey on Alcohol and Related Conditions. Journal of the American Geriatric Society, 20, 380-390. doi:10.1097/JGP.0b013e31820d92e7

Shughart, W.F. (2006). Katrinanomics: The politics and economics of disaster relief. Public Choice, 127, 31-53. doi: 10.1007/s11127-006-7731-2

The White House (2005). Katrina lessons learned. Chapter 5. Retrieved from https://georgewbush-whitehouse.archives.gov/reports/katrina-lessonslearned/chapter5.html.

Torgusen, B.L. \& Kosberg, J.I. (2008). Assisting older victims of disasters. Journal of Gerontological Social Work, 47(1-2), 27-44. doi: 10.1300/J083v47n01_04

U.S. Department of Homeland Security. (n.d.) Seniors. Retrieved from https://www.ready.gov/seniors

Walsh, J., Gibson, A. \& Brown, L.M. (2016). Peace of mind's pricetag: The psychological costs of financial stressors on older adults' post-disaster. Translational Issues in Psychological Science, 2(4), 408-417.

Weisler, R.H., Barbee, J.G. IV, \& Townsend, M.H. (2006). Mental health and recovery in the Gulf Coast after Hurricanes Katrina and Rita. Journal of the American Medical Association, 296(5), 585-588. doi:10.1001/jama.296.5.585 